УДК $347.91 / .95$

DOI https:// doi.org/10.32837/yuv.v0i3.1938

Н. Сергієнко,

кандидат юридичних наук,

старший викладач кафедри публічного та приватного права

Київського університету імені Бориса Грінченка

\title{
ВІДНОВЛЕННЯ ВИКОНАВЧОГО ПРОВАДЖЕННЯ: ПРОБЛЕМИ ПРАВОВОГО РЕГУЛЮВАННЯ
}

Наука виконавчого процесу в Україні ще $є$ відносно молодою та перебуває у стані розбудови. Однак значимість наукового осмислення сфери виконавчого процесу важко переоцінити, адже розроблення теоретичного фундаменту діяльності з примусового виконання рішень є основою виваженого та збалансованого примусового виконання. А між тим грунтовних наукових досліджень питань, пов'язаних із виконавчим процесом, не так уже й багато. Зокрема, питання відновлення виконавчого провадження розглядаються вченими-юристами найчастіше в контексті загальної проблематики примусового виконання рішень, а самостійні наукові розробки саме цієї теми непоширені. Наукове дослідження відновлення виконавчого провадження потребує окремої уваги, оскільки має суттєвий вплив на динаміку виконавчого процесу. Окремі питання відновлення виконавчого провадження були досліджені С.Я. Фурсою, Є.I. Фурсою, С.В. Щербак, Л.В. Крупновою, Л.С. Малярчук та деякими іншими вченими-юристами. Однак, як видається, сфера відновлення виконавчого провадження ще не $є$ вичерпаною науковим вивченням, а отже, є актуальною та нагальною для наукових розробок.

Метою цієї наукової статті автор визначає дослідження сутності відновлення виконавчого провадження та правового регулювання цього інституту виконавчого процесу. Завданнями статті $€$ : а) визначити сутність відновлення виконавчого провадження та іï різницю від сутності повороту виконання рішення; б) виробити уніфікований алгоритм відновлення виконавчого провадження.

С.Я. Фурса, Є.I. Фурса, С.В. Щербак визначають відновлення виконавчого провадження як продовження виконання вимог виконавчого документа державним виконавцем на забезпечення процесуальних гарантій стягувача, спрямованих на повне та правильне виконання рішення [1, с. 421]. Загалом питання відновлення виконавчого провадження регулюються приписами ст. 41 Закону України «Про виконавче провадження», але у цих приписах йдеться тільки про два випадки відновлення виконавчого провадження: 1) у разі якщо постанова виконавця про закінчення виконавчого провадження визнана судом незаконною чи скасована; 2) у разі якщо постанова виконавця про повернення виконавчого документа стягувачу визнана судом незаконною чи скасована (передбачено, що за наявності таких підстав виконавець виносить постанову про відновлення виконавчого провадження не пізніше наступного робочого дня зі дня одержання виконавцем відповідного рішення. А вже після цього стягувач, суд або орган (посадова особа), яким повернуто виконавчий документ, зобов'язані у місячний строк зі дня надходження постанови про відновлення виконавчого провадження пред'явити його до виконання. 
Якщо цього зроблено не буде, то виконавче провадження підлягатиме закінченню у зв'язку з таким непред'явленням (п. п. 13 ч. 1 ст. 39 Закону України «Про виконавче провадження»).

У юридичній літературі можна зустріти твердження, що законодавством передбачена можливість відновлення виконавчого провадження за рішенням суду (ст. 41 Закону № 1404VIII) [2, с. 251]. Проте з таким твердженням не можна погодитися, адже приписи ті є ж ст. 41 Закону України «Про виконавче провадження» передбачають, що виконавче провадження підлягає відновленню за постановою виконавця, це по-перше, а по-друге, встановлення незаконності закінчення виконавчого провадження чи повернення виконавчого документа стягувачу не тотожне відновленню виконавчого провадження та автоматично не породжує останнє: перше може бути здійснено судом, друге виконавцем.

Також підставами відновлення виконавчого провадження є:

- допуск судом (виноситься ухвала) повторного виселення особи, яка знову вселилася в приміщення, з якого була виселена. Виконавче провадження у такому разі підлягає відновленню за постановою державного виконавця (ч. 10 ст. 66 Закону України «Про виконавче провадження);

- подальше перешкоджання боржником проживанню (перебуванню) стягувача у приміщенні, в яке його вселено. Стягувач має право звернутися до державного виконавця із заявою про відновлення виконавчого провадження (ч. 6 ст. 67 Закону України «Про виконавче провадження»).

За останніх двох підстав не йдеться про потребу повторного пред’явлення до виконання виконавчого документа. У раховуючи наведене, не можна погодитися 3 твердженням про те, що відновленню виконавчого провадження передує процедура оскарження постанов державного виконавця про закін- чення виконавчого провадження, про повернення виконавчого документа стягувачеві [1, с. 421-422].

Отже, грунтуючись на законодавчо визначених підставах відновлення виконавчого провадження, сутність відновлення виконавчого провадження можна розуміти як «реверс»- повернення правовідносин з-за меж виконавчого процесу назад, у межі виконавчого процесу у зв'язку з тим, що: 1) визнано незаконним та скасовано завершення виконавчого провадження (що мало місце через його закінчення чи повернення виконавчого документу стягувачеві), отже, мала місце протиправність завершення виконавчого провадження; 2) для фактичного, адекватного та швидкого поновлення прав стягувача слід учинити знову виконавчі дії, які вже були вчинені у виконавчому провадженні, котре було завершене (зокрема, знову виселити боржника, вселити стягувача, тобто має йтися про однотипну виконавчу дію). Отже, у приписах ч. 6 ст. 67 Закону України «Про виконавче провадження» мало радше йтися не про будь-яке перешкоджання боржником вселеному стягувачу як підставу для відновлення виконавчого провадження, а саме про потребу повторного вселення стягувача, адже відновлене виконавче провадження в даному разі не може стати виконавчим провадженням з учинення виконавцем дій, не обумовлених прямо виконавчим документом. У цьому контексті влучно резюмовано С.Я. Фурсою, Є.І. Фурсою та С.В. Щербак, що відновлене виконавче провадження здійснюється надалі в загальному порядку відповідно до правил Закону України «Про виконавче провадження», крім виконавчого провадження за виконавчим документом про вселення, що після повторного примусового вселення до житлового приміщення підлягає закінченню 3 винесенням відповідної постанови державного виконавця [1, с. 424]. Останній висновок буде 
справедливий і стосовно виселення. Варто зазначити, що законом не обмежено, скільки разів може бути відновлено виконавче провадження (у тому числі й стосовно вчинення вселення чи виселення), отже, таке відновлення можливе без обмежень у кількості.

У контексті відновлення виконавчого провадження цікавими $€$ приписи п. 15 розділу VIII Інструкції з організації примусового виконання рішень: у разі скасування судом заходів забезпечення позову за завершеним виконавчим провадженням ... виконавець не пізніше наступного робочого дня виносить постанову про зняття арешту з майна боржника без винесення постанови про відкриття чи відновлення виконавчого провадження. Копія постанови виконавця про зняття арешту 3 майна боржника не пізніше наступного робочого дня зі дня винесення надсилається сторонам та до відповідного органу (установи) для зняття арешту. Постанова про зняття арешту 3 майна приєднується до матеріалів виконавчого провадження [3]. Із приводу наведеного аргументовано зазначає Л.С. Малярчук: виконавчим документом буде лише ухвала про забезпечення позову, а ухвала, якою вжиті судом заходи скасовуються, - вже ні, хоча вона і постановляється внаслідок застосування забезпечувальних заходів, але, по суті, стосується ухвали, якою вирішено це питання, а отже, $є$ похідним документом. Таким чином, ухвала про скасування забезпечення позову направляється органам примусового виконання, проте не буде окремим виконавчим документом; більше того, нині фактично виконується поза виконавчим провадженням, що було відкрите на підставі ухвали про забезпечення позову [4, с. 97-98].

Звісно, вчинення виконавцем виконавчих дій поза виконавчим процесом - це нонсенс. Однак і про відновлення виконавчого провадження у зв'язку із скасуванням забезпе- чення позову теж неможливо говорити, адже не йдеться ні про встановлення протиправності завершення виконавчого провадження, ні про потребу вчинення виконавчої дії, що однотипна тій виконавчій дії, яку виконавець учинив у виконавчому провадженні, яке було завершено, для фактичного, адекватного та швидкого поновлення прав стягувача (що є суттю відновлення виконавчого провадження, про що йшлося вище). Як видається, ухвала про скасування заходів забезпечення позову має виконуватися за аналогією із судовим рішенням, яким допущено поворот виконання рішення, адже вони споріднені тим, що відпала підстава виконання рішення, яке підлягало примусовому виконанню. Отже, суд має звернути до виконання таке судове рішення, а особа, в інтересах якої воно ухвалено, має право пред’явити відповідний виконавчий документ (чи судове рішення, яке одночасно $€$ й виконавчим документом) до примусового виконання, виконавець-відкритивиконавчепровадження (за відсутності у цьому перешкод).

Окремо слід артикулювати сутнісну різницю між поворотом виконання рішення та відновленням виконавчого провадження:

- поворот виконання не пов'язаний із протиправністю вчиненого примусового виконання чи потребою ще раз учинити ту ж саму виконавчу дію, що була вчинена у завершеному виконавчому провадженні (якраз навпаки: поворот виконання ще іноді називають «зворотним виконанням» - процесуальною формою поновлення судом порушених прав боржника, що забезпечує можливість зворотного стягнення зі стягувача всього безпідставно отриманого ним за скасованим рішенням [5, с. 39]), він пов'язаний із тим, що (підстава повороту виконання) відпала повністю/частково підстава виконання рішення, яке підлягало примусовому виконанню. Відновлення виконавчого 
провадження не пов'язано з тим, що відпала повністю/частково підстава виконання - рішення, яке підлягало примусовому виконанню (навпаки, у разі відновлення виконавчого провадження рішення, що підлягає примусовому виконанню, залишається незмінним). Відновлення виконавчого провадження пов'язано (підстава відновлення виконавчого провадження) 3 установленням протиправності завершення виконавчого провадження чи 3 потребою вчинення виконавчої діі, що однотипна тій виконавчій дії, котру виконавець учинив у виконавчому провадженні, яке було завершено, для фактичного, адекватного та швидкого поновлення прав стягувача;

- якщо судом допущено поворот виконання, то гіпотетично (якщо відповідний виконавчий документ буде пред’явлено до примусового виконання) матиме місце нове виконавче провадження. У разі відновлення виконавчого провадження продовжується те виконавче провадження, яке було спочатку завершене, а потім відновилося.

Як убачається 3 приписів ст. ст. 41, 66, 67 Закону України «Про виконавче провадження», залежно від підстав відновлення виконавчого провадження законодавець пропонує різні алгоритми такого відновлення та різну послідовність дій відповідних суб'єктів без будь-яких обгрунтувань, що є методологічно невірним: інститут відновлення виконавчого провадження повинен мати логічну та послідовну структуру.

Ураховуючи сутність та правове регулювання сфери відновлення виконавчого провадження, пропонується уніфікований алгоритм відновлення виконавчого провадження:

1. Особа, на користь чи в інтересах якої безпосередньо або через представника ініціює відновлення виконавчого провадження:

а) пред'являє до примусового виконання виконавчий документ разом із заявою про відновлення виконавчого провадження (якщо мало місце встановлення протиправності завершення виконавчого провадження). Як видається, саме такий суб’єкт повинен пред'являти до примусового виконання виконавчий документ для відновлення виконавчого провадження, адже він $€$ зацікавленим у такому виконанні. Ні суд, ні орган (посадова особа), яким повернуто виконавчий документ (про що йдеться у чинній редакції ч. 2 ст. 41 Закону України «Про виконавче провадження»), таке пред’явлення не вправі здійснювати, оскільки зацікавленості у примусовому виконанні вони не мають. До того ж, як вірно зазначається деякими науковцями-юристами, завершальна стадія цивільного процесу - вже не виконавче провадження, не виконання судових рішень, а звернення судового рішення до виконання [6, с. 27]; сторони $є$ головними та обов'язковими учасниками виконавчого провадження, що мають особисту заінтересованість у результатах виконавчих дій [1, с. 230]. Строк для здійснення такого пред'явлення - один місяць зі дня, коли особа дізналася або повинна була дізнатися про встановлення протиправності завершення виконавчого провадження. Тут варто виходити з того, що особа має з розумною періодичністю цікавитися своєю справою. Як приклад див. Рішення ЄСПЛ від 03.04.2008 у справі «Пономарьов проти України» (заява № 3236/03): «...сторони в розумні інтервали часу мають уживати заходів, щоб дізнатися про стан відомого їм судового провадження...» [7]; Постанову Верховного Суду у складі колегії суддів Касаційного адміністративного суду у справі № 0870/8014/12 від 15.05.2019: «... сторона, яка задіяна в ході судового розгляду, зобов'язана 3 розумним інтервалом часу сама цікавитися провадженням у іiі справі...» [8];

б) звертається до виконавця із заявою про відновлення виконавчого провадження (ч. 6 ст. 67 Закону 
України «Про виконавче провадження») або з такою заявою та ухвалою суду (ч. 10 ст. 66 Закону Украіни «Про виконавче провадження»), якщо підстава відновлення виконавчого провадження - це потреба вчинення виконавчої дії, що однотипна тій виконавчій дії, яку виконавець учинив у виконавчому провадженні, яке було завершено, для фактичного, адекватного та швидкого поновлення прав стягувача. Строк для здійснення такого звернення - один місяць зі дня, коли особа дізналася або повинна була дізнатися про виникнення відповідних підстав для відновлення виконавчого провадження.

2. Отримавши зазначені документи, виконавець: а) виносить постанову про відновлення виконавчого провадження, якщо подані всі необхідні документи (заява, виконавчий документ), та продовжує примусове виконання в загальному порядку (якщо відновлення виконавчого провадження відбулося через встановлення протиправності завершення виконавчого провадження) або вчиняє повторне виселення особи чи повторне вселення (див. ст. ст. 66, 67 Закону України «Про виконавче провадження»); б) виносить постанову про відмову у відновленні виконавчого провадження, якщо: не подано заяви про відновлення виконавчого провадження та/або виконавчого документа, за яким слід здійснювати примусове виконання / ухвали суду про повторне виселення; пропущено строк для звернення до виконавця для відновлення виконавчого провадження.

Ураховуючи наведене вище в сукупності, приписи ст. 41 Закону України «Про виконавче провадження» варто змінити.

Узагальнюючи наведене, слід підкреслити, що сутність відновлення виконавчого провадження можна розуміти як «реверс» - повернення правовідносин з-за меж виконавчого процесу назад, у межі виконавчого процесу у зв'язку з тим, що: 1) визнано незаконним та скасовано завершення виконавчого провадження (що мало місце через його закінчення чи повернення виконавчого документу стягувачеві), отже, мала місце протиправність завершення виконавчого провадження; 2) для фактичного, адекватного та швидкого поновлення прав стягувача слід учинити знову виконавчі дії, котрі вже були вчинені у виконавчому провадженні, яке було завершене (зокрема, знову виселити боржника, вселити стягувача, тобто має йтися про однотипну виконавчу дію). Сутнісно відновлення виконавчого провадження істотно відрізняється від повороту виконання рішення та одночасно з ним застосовуватися не може (адже і суть різна, і підстави застосування різні). Відновлення виконавчого провадження повинно мати чіткий уніфікований алгоритм, який i пропонується у цій статті, з його повним обгрунтуванням.

Видаються перспективними подальші наукові розвідки за тематикою відновлення виконавчого провадження, зокрема правомочності учасників виконавчого процесу, щодо яких, ураховуючи обсяг даної статті, неможливо було торкнутися у цьому дослідженні.

У науковій статті автором розглянуто сутність відновлення виконавчого провадження, а також визначено різницью між відновленням виконавчого провадження та поворотом виконання рішення. Обтрунтовано авторський алгоритм відновлення виконавчого провадження. Автор констатує, що виконавче провадження підлягає відновленню за постановою виконавия; встановлення незаконності закінчення виконавчого провадження чи повернення виконавчого документа стягувачу не тотожне відновленню виконавчого провадження та автоматично не породжуе останне. Встановлення 
незаконності закінчення виконавчого провадження чи повернення виконавчого документа стягувачу може бути здійснено судом, а відновлення виконавчого провадження здійснюється виконавцем. Підставами відновлення виконавчого провадження $є:$ 1) у разі якщцо постанова виконавия про закінчення виконавчого провадження визнана судом незаконною чи скасована; 2) у разі якщо постанова виконавия про повернення виконавчого документа стягувачу визнана судом незаконною чи скасована; 3) у разі допущення судом (виноситься ухвала) повторного виселення особи, яка знову вселилася у приміщення, з якого була виселена; 4) у разі якщо боржник $i$ надалі перешкоджає проживанню (перебуванню) стягувача у приміщенні, в яке його (стягувача) вселено. Обгрунтовано, що сутність відновлення виконавчого провадження зводиться до повернення правовідносин з-за меж виконавчого процесу назад, у межі виконавчого процесу, у зв'язку з тим, щз: 1) визнано незаконним та скасовано завершення виконавчого провадження (що мало місце через його закінчення чи повернення виконавчого документу стягувачеві), отже, мала місце протиправність завершення виконавчого провадження; 2) для фактичного, адекватного та швидкого поновлення прав стягувача слід учинити знову виконавчі дії, котрі вже були вчинені у виконавчому провадженні, яке було завершене (зокрема, знову виселити боржника, вселити стягувача, тобто має йтися про однотипну виконавчу дію). Неможливим є одночасне застосування відновлення виконавчого провадження та поворот виконання рішення, оскільки вони відрізняються як сутнісно, так $i$ за підставами застосування. Оскільки приписи чинного законодавства передбачають різні алгоритми від- новлення виконавчого провадження залежно підстав такого відновлен$н я$, без будь-яких обтрунтувань, у статті пропонуеться авторський уніфікований алгоритм відновлення виконавчого провадження.

Ключові слова: виконавчий процес, виконавче провадження, відновлення виконавчого провадження.

Sergiienko N. Renewing of executive process: problems of legal regulation

in the scientific article the author have explored the essence of renewing of executive process, also the difference between renewing of executive process and turning back the execution of decision has been scrutinized. In the scientific article the author have grounded her own authorial algorithm how to renew the executive process. In the article the author have stated that executive process is to be renewed by the rule of executor; stating that the executive process had been completed (by finishing the executive process by or giving back the executive document to the creditor) in illegal manner has not stated as equal to renewing of executive process and has not caused the mentioned above. Stating that the executive process was finished or giving back the executive document to the creditor was made in illegal manner is the competence of court, but renewing of executive process is the competence of executor. The grounds of renewing of executive process are as follows: 1) if the executor's rule on finishing the executive process has been stated by court as illegal or cancelled; 2) if the executor's rule on giving back the executive document to the creditor has been stated by court as illegal or cancelled; 3) if court has allowed (has given approval) to evict repeatedly the person, who illegally lodged the apartment after his/her eviction; 4) if the debtor repeatedly has being blocked 
creditor's living in the apartment, where he/she (creditor) had been lodged. The author of the article have grounded that the essence of renewing of executive process focuses on turning back the relations from the outside of executive process to the frontiers of executive process, it is necessary because of stating illegal the completion of executive process (finishing the executive process or giving back the executive document to the creditor), so that, it had been stated the illegality of completion of executive process; or 2) necessity of factual, adequate and rapid renewing creditor's rights executive acts, that have been already made in completed executive process, are to be made (to evict debtor, to lodge creditor we tell on twin executive act). It is impossible to use renewing of executive process and turning back the execution of decision in a one moment, because they are essentially different and different in the grounds of their using. Legislative regulations prescribes different algorithms for renewing the executive process, depending on grounds of this renewing, that's why in the scientific article has been offered the authorial unified algorithm how to renew the executive process.

Key words: executive process, executive procedure, renewing the executive process.

\section{Література}

1. Фурса С.Я., Фурса Є.I., Щербак С.В. Закони України «Про державну виконавчу службу», «Про виконавче про- вадження», «Про виконання рішень та застосування практики Європейського суду з прав людини» : науково-практичний коментар / за заг. ред. С.Я. Фурси; Центр правових досліджень. Київ : КНТ, 2008. 1172 c.

2. Крупнова Л.В. Система виконавчого провадження в Україні: теоретико-правові та праксеологічні аспекти : дис. ... д.ю.н.: 12.00.07 - адміністративне право i процес; фінансове право; інформаційне право (081 - право). Київ. 2018. 455 c.

3. Інструкція з організації примусового виконання рішень : Наказ Міністерства юстицї України від 02.04.2012 № 512/5 (у редакціï від 29.09.2016 № 2832/5). Верховна Рада України. URL: https:// zakon.rada.gov.ua/laws / show/ z0489-12 (дата звернення: 06.07.2020).

4. Малярчук Л.С. Ухвала суду як виконавчий документ - підстава для відкриття виконавчого провадження. Jurnalul juridic național: teorie și practică. 2019. August. P. 96-100.

5. Цивільний процесуальний кодекс України : науково-практичний коменmap : y 2-x m. / за заг. ред. С.Я. Фурси. Kuїв : Фурса С.Я., 2009. T. 2.816 с.

6. Фурса С.Я., Щербак С.В. Виконавче провадження в Україні: навчальний посібник. Київ : Атіка, 2002. 480 c.

7. Рішення ЕСПЛ від03.04.2008 у справі «Пономарьов проти України» (заява № 3236/03). Верховна Рада України. URL: https: / / zakon.rada.gov.ua/laws / show $/ 980 \_227$ ? find $=1$ \& text $=\%$ E2\% E8\% EA\% EE\% ED\#w164 (дата звернення: 07.06.2020).

8. Постанова Верховного Суду у складі колегіі суддів Касаційного адміністративного суду у справі

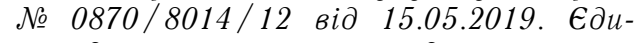
ний державний реєстр судових рішень. URL: http: / / www.reyestr.court.gov.ua / Review/81759476 (১ата звернення: 06.07.2020). 